\title{
Power and Representation in Women's Autobiographies
}

\author{
SHAFAG DADASHOVA \\ Baku Engineering University, 120, Hasan Aliyev Absheron, Baku, AZ 0101, Azerbaijan \\ Email:shafag13@mail.ru
}

\begin{abstract}
The study discusses epistemological aspects of power and the dynamics of its perception in the process of life-writing. Autobiography is presented as a specific form of epiphany. The paper suggests that writing one's own life enables the author to better understand the past. As a result of a retrospective self-analysis the writer shapes a new look at the borders of his/her personal power and the level of its dependence on others. In investigation of life-writings, a qualitative method of social sciences in combination with hermeneutics, close reading and discourse analysis reveal deep and hidden social norms, gender roles, religion, and their role in empowerment and disempowerment of the author.

The study consists of two parts. The first part is theoretical and interrogates the notion of personal power. It finds links between writing the own life and conscious empowerment, arguing that the author becomes more conscious about the own personality after having analysed the past decisions from the perspective of present times. The second part presents two autobiographies by female authors from two different Muslim cultures. These authors negotiate between the larger nationalist agenda and their own personal concerns. These autobiographies (Pakistani author Tehmina Durrani, My Feudal Lord; Azerbaijani writer Banine, Caucasian Days and Parisian Days) are the end of their authors' long silence, their revolt against the conventional norms, their decision to have an agency to confess and protest. These autobiographies are the authors' attempts to break the established matrix of perceptions, imposed norms, and gain power to build the real picture of their identity.

The study sums up with the conclusion that in spite of very similar motifs of female authors to get empowered through self-analysis, different cultures and time create specific subjectivities associated with particular historical events and geographical location.
\end{abstract}

Keywords: conformity level, empowerment, female autobiography, self-identity, Banine, Tehmina Durrani

The writer of the autobiography acts as an investigator of the own life and uses different methodologies and strategies to find the real sources of power in her life. At this point, the autobiographer takes over the role of the investigator and uses different methods which can coincide with those which are employed by the researchers-anthropologists who analyse the autobiography. The most suitable methods for the author to investigate her life and for the researcher who studies life-writings are qualitative research methods and social critic approach. In particular, hermeneutical phenomenology, close reading and discourse analysis help the investigator to go 
deeper and find out what was beyond the experiences of the writer and beyond the introduced message in the text.

The paper consists of two parts. The first part is theoretical and interrogates the notion of personal power. Autobiography writing is shown as a means of personal empowerment when the author examines the own life retrospectively and from the recent status. The second part presents two autobiographies by female authors from two different Muslim cultures. These autobiographies negotiate their authors' status as lacking power in a scope of their nationalist agenda or in exile and their own personal concerns. These autobiographies (Tehmina Durrani, Pakistani author, My Feudal Lord; Banine, Azerbaijani writer, Caucasian Days and Parisian Days) are the end of their authors' long silence, their revolt against the conventional norms, decision to have an agency to confess and protest. These autobiographies are the authors' attempts to break the established matrix of perceptions, imposed norms, and gain power to build the real picture of their identity. In these autobiographies the authors struggle against patriarchy and cultural norms which encourage women's oppression. But different cultures and time create specific subjectivities associated with particular historical events and geographical location.

Power is generally understood as domination on an object and imposition of restrictions on him/her against his/her will or not considering his/her desire and interests. Nussbaum writes that 'a critical scrutiny of preference and desire that would reveal the many ways in which habit, fear, low expectations, and unjust background conditions deform people's choices and even their wishes for their own lives' (Nussbaum 2000: 114). If a person is not interested in analysis of the background which played a crucial role in formation of his/her recent desires, $s /$ he develops a simple homogeneous attitude to and interpretation of power and justice, simplifying these concepts to the point that one is powerful if $s /$ he is free from external power, if $s /$ he is in control of his/her choices and under somebody's or something's power if $s /$ he does not have right of choice.

Lukes in his book Power writes that 'Power can be deployed to block or impair its subject's capacity to reason well, not least by instilling and sustaining misleading or illusory ideas of what is "natural" and what sort of life their distinctive "nature" dictates, and, in general, by stunting or blunting their capacity for rational judgment. Power can induce or encourage failures of rationality' (Lukes 2004: 115). The failure of rationality can be interpreted as the influence of cultures and many other factors. Lukes cites self-deception, succumbing to cognitive biases, fallacies and illusions as forms of rationality failures. Angelo Constanzo's characterization of spiritual autobiographies can probably be generalized to cover all autobiographies. '(Spiritual) Autobiography is a study in the ascending levels of awareness that the narrator has experienced and continues to experience in the mind expansion of consciousness. In (spiritual) autobiography the awareness of self is coupled with the writer's awareness of others to form a larger awareness that is gradually and constantly varying, growing and changing' (Costanzo1987: 49-50).

The center of power can be placed differently for different people: it either is placed inside, on the personal level, or outside when the subject looks for it as outside factors. Power in itself is not steady, it is a process, and this process is dynamic. The perception of this concept or conceptual process depends on the conformity level of the personality. The higher the level, the more comfortably an individual accepts the existing norms and adapts his desires to them. However, if the level of conformity is low, an individual would rather try to define or create his/her unique identity relying on his/her life as a dynamic process of personal choice.

Thus, an individual with a low conformity level searches all possible ways to scrutinize his/ her recent desires and conditions of satisfaction. Among other possible ways of this scrutiny there is writing an autobiography, which is not a mere description of the author's life, but experiencing 
the past events through self-reflection, self-evaluation and 'self-correction'. Autobiography does not claim to be a factual documentary record of its author's life. On the contrary, more essential side of this genre is what is beyond the descriptions of life events. It is also not rare, and many authors confirm that while talking about their life in the past, they could not struggle the temptation to 'correct' their attitudes to these events in hindsight. Lying and truth is another topic of analysis, but in the meaning of self-identity definition there is an ultimate, epistemological, surrealistic truth in autobiographies, because they reflect the author's recent attitude to the past events, it is an indicator of the author's present cognizance of his self-identity. Roland Barthes writes in Mythologies:

'We are therefore dealing with a real Human Comedy, where the most socially-inspired nuances of passion (conceit, rightfulness, refined cruelty, a sense of "paying one's debts") always felicitously find the clearest sign which can receive them, express them and triumphantly carry them to the confines of the hall. It is obvious that at such a pitch, it no longer matters whether the passion is genuine or not' (Barthes 1991: 16).

As Foucault says, truth and power belong to different epistemological levels, and truth is neither essential nor eternal but it is generated through 'polymorphous techniques of power' (Foucault 1977: 96). The dialectical evolution from the initial attempt of self-analysis in the beginning of self-writing to the consequential sense of maturity and satisfaction from having lived the own life again as an omniscient director of its events can result in fascinating changes in identity. Because writing the own life not only challenges the stereotypes, but it also is quitting the silence and turning a person into an agency to confess, understand, accept or protest.

Identity changes take place due to retrospective analysis, hindsight and epiphanies which the subject and at the same time the object of the writing would inevitably experience during and after illustration of the own experience. This shift in identity brings to empowerment because $\mathrm{s} /$ he feels a certain type of power over his/her life, because now s/he is not only a participant, or an observer (what also can take place), but also a creator of his/her life story with privilege to 'correct' the past events and adapt them to the recent, more mature experiences. Mark Twain has said that in any life-writing the author more frequently lies than tells the truth. But the nature of this lie is multi-layered. It is often not a lie told to deceive somebody. It is a 'correction' made to previous mistakes in order to present a more accomplished life and introduce more mature attitudes than had been taking place during the actual processes. This maturity attributes to the writer the power of understanding that (s)he is able to change his/her life. Robert Barthes in his autobiographical writing entitled Robert Barthes talks about the process of writing about his life. This passage reveals well the nature of the essence and performativity.

'La coincidence $\sim$ Coincidence I record myself playing the piano: initially, out of curiosity to hear myself; but very soon I no longer hear myself; what I hear is, 55 however pretentious it may seem to say so, the Dasein of Bach and of Schumann, the pure materiality of their music; because it is my utterance, the predicate loses all pertinence; on the other hand, paradoxically, if I listen to Horowitz or Richter, a thousand adjectives come to mind: I hear them and not Bach or Schumann. - What is it that happens? When I listen to myself having played - after an initial moment of lucidity in which I perceive one by one the mistakes I have made - there occurs a kind of rare coincidence: the past of my playing coincides with the present of my listening, and in this coincidence, commentary is abolished: there remains nothing but the music (of course what remains is not at all the "truth" of the text, as if I had rediscovered the "true" Schumann or the "true" Bach).

When I pretend to write on what I have written in the past, there occurs in the same way a movement of abolition, not of truth. I do not strive to put my present expression in the service 
of my previous truth (in the classical system, such an effort would have been sanctified under the name of authenticity). I abandon the exhausting pursuit of an old piece of myself, I do not try to restore myself (as we say of a monument). I do not say: "I am going to describe myself" but: "I am writing a text, and I call it R. B.'^T, shift from imitation (from description) and entrust myself to nomination." Do I not know that, in the field of the subject, there is no referent?' (Hill and Wang, 1977).

As an autobiography is not a mere description of the past, but representation of one's life through self-analysis, self-representation and self-evaluation, it requires different methodologies for the writer to interpret and understand the own life and for the reader to understand the author's life. The author aims to investigate and find clues for self-revelation, the reader, on the other hand, tries to find the details which remained unsaid or which were deliberately or unconsciously silenced by the writer. In case the author aims at self-recognition through writing an autobiography, s/he needs to emphasise the link between the personal and the social, create an alternative life-story, which challenges dominant or conventional styles of individual and collective cognizance. 'The autobiography situated at the border between public and private discourse, and in which the present perspective mixes with that of the past, enables a registration of changes at both individual and social levels' (Baisnée, 1977).

Both the writer and the reader of the autobiography consciously or unconsciously use diverse methodologies, which can be different from each other, can coincide and can also be ramifications of one method. The writer's methodology aims at justification of his/her significance in the world and power in life. The reader, on the other hand, targets at finding common points between the author's personal values, choices and those of different communities to which the writer formally belongs, or his/her dependency upon outside factors. Another reason for reading autobiographies can be to learn the experience of people similar to the reader's position. Susan Stanford Friedman notes that:

The individual concept of the autobiographical self that pervades Gusdorf's work raises serious theoretical problems for critics who recognize that the self, self-creation and self-consciousness are profoundly different for women, minorities, and many non-western peoples (Friedman 1995: 7). The author investigates different stages of the own life, studies self-efforts and self-sacrifices contrasting them to forced efforts and sacrifices. The process of scrutinizing of self-reliance sharpens the author's sense of self-recognition, who contextualises himself though transcending the internal world upside and trying to harmonise it with his social context.

Among the questions the author asks him/herself is the reason of underlying prejudices. $\mathrm{S} /$ he goes back to the crucial points of his/her life and, how existentialists call it, reaches border situations where the tides of his/her life changed, wheres s/he had to stop and evaluate the conditions, but failed to do it, or did but in hindsight it seems insufficient. But now $\mathrm{s} / \mathrm{he}$ is privileged to have known the consequences of the past decisions and also is provided with the power to look at them in a wider context of the results to which that decision had brought. Besides, s/he is free from such emotional burdens as fear, hesitance, uncertainty, which most probably s/he experienced when was inside all those processes and the decisions to be made by him/her could be crucial for the future. One of the most common features of autobiographies is longing for change and many autobiographies can be considered as a means or an attempt to live differently from the present future.

The look from outside as an omniscient and omnipotent creator justifies the author in the position of a ruler and director. 'Change requires both processes of interruption and continuity in order to advance newer modes of doing' (Papacharissi 1995: 4). Autobiographical studies 
require deep investigations of the socio-cognitive interface of personal motifs of the author and socially shared mental representations of his/her surroundings. Sociolinguistic methods could reveal to what extent a certain decision was free of social influences and how much 'personal' and how much 'independent' were the writer's 'personal independent' decisions and approaches. As the autobiographer is eager to search hidden relations of power in order to define for him/ herself whether s/he was a powerful ruler or ruled by an external power, the reader and investigator of the autobiography also tries to find the real, often concealed agencies of power in order to identify diverse social relationships. Analysis of two Muslim female writers' autobiographies can bring to interesting results about similar motifs of female authors to get empowered through self-analysis and show how different cultures create specific subjectivities associated with particular historical events and geographical location.

\section{ABOUT THE AUTHORS}

Azerbaijani immigrant writer Banine was a granddaughter of the Baku's wealthiest oil magnates, Shamsi Asadullayev on her father's side and Mirza Agha Musa Naghiyev on her mother's side. She was the youngest of four sisters in her family. Her father Mirza Asadullayev, besides of running a huge business, also served as the Minister of Trade and Industry under Azerbaijani Democratic Republic (1918-1920). Banine's autobiographical books entitled Caucasian Days and Parisian Days are written in 1946 and 1947, respectively. The first book describes the author's life in Baku and the second one illustrates her life in Paris.

Durrani was born into an influential family. Her father, Shahkur Ullah Durrani, was the Managing Director of Pakistan International Airlines and Governor of the State Bank of Pakistan. Tehmina's maternal grandfather Liaqat Hayat Khan, Khattar was a Prime Minister of the former princely state of Patiala for eleven years. Durrani's autobiography written in 1991 and titled My Feudal Lord is about the abuse by Khar, her second husband with whom she was married for thirteen years and had four children.

These two autobiographies of two female writers are chosen for comparative analysis because of similarities in their authors' backgrounds. The common points between them was their influential families, their education and non-conformity. Banine from her childhood tries to identify herself and prove to be different from the female members of her family. Durrani understands her unsuitability to be a 'good daughter' and failures to gain approval from her mother.

\section{STRUCTURE OF THE AUTOBIOGRAPHIES UNDER CONCERN}

Banine's autobiography consists of two books. The first book entitled Caucasian Days is devoted to the author's childhood and early youth years in Azerbaijan, which she left in 17 because Soviet occupants in 1920 came and turned it to a Socialist Republic. 'I woke up to the sound of the "Internationale" playing in the street,' Banine recalled, as she recounted the Red Army's march into the Azerbaijani capital, Baku. 'When I got up on April 27, 1920, I saw soldiers not looking Azerbaijani by either their looks, or their uniform. Those were Russian soldiers.' The Azerbaijani army 'disappeared without firing a single shot', she continued. 'The republic was destroyed ... I witnessed the end of a world with my own eyes' (Banine 1992: 106).

In the first part of her autobiography Banine illustrates the life of a girl who is surrounded with all luxurious comforts of the affluent life but who also constantly contrasts her family's values, attitudes, behaviour and appearances with those of her German nanny whom she adored. Banine writes that she did not care about the wealth her family owned. She dreamt to go to France, which seemed to her as an incarnation of freedom, escape from collective decisions for 
her and interferences to her life. She dreams of a better life rebelling against certain aspects her Muslim heritage imposes.

The second part of Banine's autobiography is entitled Parisian Days and in this part she talks about her life in Paris. Unlike the comfortable wealthy life in Baku, the life in Paris does not promise anything on the tray. Banine has to work to earn her living. It inspires her, gives her power and strength. She works as a model, translator, music teacher, secretary and never seems to be missing of her careless affluent life in Baku, because as she mentions in the beginning of Caucasian Days, she did not care about the wealth of her family and in France she was independent and responsible for her life.

My Feudal Lord consists of three parts. The titles given to the parts by the author are highly allusive. The first part is titled as 'Lion of Punjab', the second part is called 'Law of Jungle' and the last third part is named as 'Lioness'. This reminds of the hell, purgatory and paradise in The Divine Comedy and the content of the autobiography shows a dynamic impulse from obedience, silence, feeling guilty to self-recognition, self-identity through self-analysis, self-revelation, breaking of silence and confessions.

In the first part Tehmina, characteristically for many woman autobiographers, talks a lot about her mother and how she was making her be obedient: 'The lesson was clear and I learnt it well: blind acquiescence was necessary to gain approval; being yourself earned only condemnation. I was acceptable only when I was unlike myself - whoever that was - because I wore a mask of submission. I developed a personality that was against my true nature, but compatible with mother's. Inwardly I became confused and sometimes ashamed that what I must really be was incorrect and unacceptable' (Durrani 1992: 14).

\section{MARRIAGE}

Banine's mother died on her birth. Banine's father was not patriarchal and dogmatic towards his children. But she chose self-sacrifice to help her family. The authorities of the newly established Soviet Republic arrested Banine's father. Then she was 15 years old, and in order to help her father to be released from the prison, receive a passport and be able to leave the country, she felt obliged to marry a man she did not love but who could provide these documents and freedom to her father. Was it a self-negation instinct of an Oriental woman who considers herself to be an attachment, a helping hand to a man, self-sacrifice to make his life easier or cozier, or her desire to prove her feminine power, she never tells. It was her choice but she felt that this way was the only one she could choose. 'Often in such social structures, that is in collectivistic societies, individuals are ignored, their rights subdued and expected to confirm to certain group norms. Collectivism therefore, favors oppressed women. This rhetoric of collectivity is popularized as such, one for all and all for one, only to perpetuate the status quo which is obviously more brutally loaded in favor of the men' (Jafri 2008: 102).

Banine was in love with Andrei, a member of the Revolutionary Council, when her father was in prison of Russian Revolutionists. Jamil, a 35-year old relative, promised to help him release from there and Banine knew that he was going to offer her marriage instead. Banine writes about it: 'It is true that I received my education from Europeans, have read many novels, now was surrounded by the ideas of Bolshevism and Liberalism, but in the bottom of my heart there was a belief that "a husband cannot be chosen" (Durrani 1992: 28).

When after 9 months Jamil, with the help of his friend who was a commissar, managed to release Banine's father she was planning to elope with Andrei. She was conscious of their belonging to opposite political classes and was also terribly worried about her father's reaction 
to her decision. She was also thinking about how her grandmother would reflect if she knew that her granddaughter wants to marry a non-Muslim, furthermore, a representative of a group which stole her son, house and money from her. Banine thought that 'death was better than to talk about this' (Banine 1992: 112), but she also hated to think that Andrei could leave without her. While falling apart in her hesitations, she was forestalled by her father with his talk about her marriage with Jamil:

'You know that Jamil freed me from the jail. But I also need a passport to go abroad. You know how difficult it is. Jamil's commissar friend can help me. I cannot force you into marriage with him, but I am asking you to think about all these. He is educated, brave and loves you. Why to reject him? But I am repeating it again. Nobody forces you into marriage. Think about it and tell me your decision tomorrow' (Banine 1992: 95).

Banine describes her emotions after this conversation very eloquently. She writes that her father wanted to remind her about children's duty before their parents, he wanted to sacrifice her and escape himself. The next day when she was asked about her decision, she answered automatically that let it be as her father wanted. She named herself a captive in the claws of cowardice, which is an interesting point for me. From blaming her father for sacrificing her to obtain freedom and power she transfers her analysis to herself. I wonder how would this episode have been written if the author would have written it in Azerbaijan. A 40-year-old woman in Paris, whom Banine was while writing her book, could see the motifs of hesitation to elope in 15-year-old Azerbaijani girl's to be cowardice. And the close reading of the text shows that at the time of decision making she was accusing her father. How would be the description of her motifs if she did not leave Azerbaijan and was not empowered by the notion of individualism which nurtured her within 24 years, the time span from her first arrival in Paris till the time of her autobiography writing?

She wrote that she was also trying to get along with her fate and hoping that still everything could change. After a few days Andrei wrote a letter to invite her to his office which used to be the mansion of her family before the revolutionists' coming and driving them away from there. Among other things about their leaving together Andrei said, 'You are young and charming. I want to turn you into a brave and useful person. Do you agree?' 'I wanted to believe that I can change and I said confidently, "Yes, I agree", and I felt that I could change' (Banine 1992: 99). The beginning of this change would be resistance against the 'patriarchal courtesy' of her family which provided her with the choice in the frames of considerations of her prescribed duties. The day for them to elope was arranged, and when it came, she could not stop thinking that this step of her could destroy her father's only hope to go abroad and reunite with her family (Banine's two sisters, stepmother and little stepbrother were in Paris). She asked her cousin to see Andrei at the arranged time and explain the situation. After several days she silently endures all wedding ceremony and at her 15 becomes a 35 -year-old Jamil's wife. What she mentions is that her husband adored her and stood all her caprices. But Banine was sure that Jamil considered her adorable and sacred because she was coming from one of the richest families of Caucasus and not because of her personality. She hated him even more.

Durrani's reason for marriage was different but it was also stemmed in powerlessness or in an attempt to gain power ... 'We were being raised to be schizophrenic; an appearance of perfection was more important than genuine feelings. There was no question of discovering oneself. Identity and individuality were crushed. Personality failed to develop. My mind became a sanctuary for secret thoughts of escaping from this household. But for that there was no other goal in life but marriage' (Durrani 1992: 19). 
In both of the analysed autobiographies the authors are extremely courageous. Banine openly talks about the relationships in her family which was revered and admired as being exemplary, Tehmina goes even further by sharing experiences of her marital life breaking the established and approved by their communities solid silence.

The study argues that these functions are interwoven with the main focus on personal motives, because only having understood the self, one becomes able to make others conscious of shared problems and inspire to find solutions. Autobiographies help understand subconscious preferences and choices of different cultures and accept diversities. Autobiographies help the authors develop their subjective knowledge, encourage them to approach to events in analytic ways. Taking control of the own life through creating the self as a text, attributing to the new self such qualities as independent thinking and evaluating ability leads to empowerment which kindles desire to stimulate raising of consciousness in others, showing them their own experience within this process of cognitive development. The psychological interruptions take place when the person feels developed enough to move to the next stage, or in other words, when they have been empowered enough to think of further positive changes in their personality and relationships. The social interruption happens when the author begins to develop in her subjective knowledge reassessing her relationships at very diverse levels. She ceases toxic relationships, imposing authoritative voices in her life and builds new relationships based on harmony and justice.

Life-writing serves to demonstrate to readers the whole process of the author's cognitive development. In individual stories, approaches and analyses, they find typicalities and similar patterns. Commonness stimulates identification and develops empathy which consequently encourages global dialogues. The autobiographical discourse creates a context informing about subtleties of all aspects of human lives.

My findings indicate that life writings are cognitive and social activities. Being both author and reader oriented, they serve as a participatory methodology aimed at consciousness raising, strengthening of empathy and increasing intercultural understanding. Familiarity with and consciousness of internal norms and relationships in other cultures help readers be comfortable with culture-sensitive issues. This study suggests that investigating autobiographies social researchers can obtain a direct access to authentic sources where gender-based expectancies are shaped, how identities and interests of actors within the culture are being formed in both direct and non-direct coercive senses. It also suggests the possibility for further research, examining similar patterns of cognitive development in different cultures. Studying how norms emerge in different contexts would also enable one to relativise norms as indicative of locally/historically constructive norms rather than as overarching diktats.

Both authors are given a sense of empowerment gradually through self-analysis, discovering their identity and status. Describing their lives and past approaches as something which was not 'ideal' or 'right', the inclusion of a great number of people, also their own compatriots, into their private life is breaking away with the prescribed identity and finding the own self, turning into a ruler of the own life.

In the state of extreme powerlessness when death seems the only solution, Banine makes a decision to write. In the crucial point of her life, she feels herself desperately ready to face the pains and grieves involved in her past experiences, long-lasting silences. Durrani decides to divorce, talk about her previous unbearable life, quit it and continue from a new page. Autobiography writing becomes a means to get empowered and gain control over the own life. 


\section{References}

1. Baisnée, V. 1977. Gendered Resistance, The Autobiographies of Simone de Beauvoir, Maya Angelou, Janet Frame and Marguerite Duras. Amsterdam: Rodopi.

2. Banine. 1992. Caucasian Days. Baku (in Azerbaijani).

3. Barthes, R. 1991. Mythologies. New York: The Noonday Press.

4. Barthes, R. 1977. Roland Barthes by Roland Barthes. Hill and Wang.

5. Costanzo, A. 1987. Surprising Narrative: Olaudah Equiano and the Beginning of Black Autobiography. New York: Greenwood.

6. Durrani, T. 1992. My Feudal Lord. New Delhi: Sterling Publishers.

7. Foucault, M. 1977. Power/Knowledge: Selected Interviews and Other Writings. New York: Pantheon Books.

8. Friedman, S. S. 1988. "Women's Autobiographical Selves: Theory and Practice", in Women, Autobiography, Theory: A Reader, eds. S. Smith and J. Watson. Madison: The University of Wisconsin Press.

9. Jafri, A. 2008. Honour Killing: Dilemma, Ritual, Understanding. Karachi: Oxford University Press.

10. Lukes, S. 2004. Power: a Radical View. Palgrave Macmillan.

11. Nussbaum, M. C. 2000. Women and Human Development: The Capabilities Approach. Cambridge University Press.

12. Papacharissi, Z.; Easton, E. 2013. "In the Habitus of the New", in A Companion to New Media Dynamics, ed. J. B. Hartley. Oxford: Wiley-Blackwell.

\section{Galia ir atstovavimas moteru autobiografijose}

